\title{
Suggestions for Statistical Records, I
}

This is the first part of an article which brings a fresh view of the subject of library statistics and which will be continued in a subsequent number of College and Research Libraries.

$\mathrm{T}$ HAT MOST librarians dislike statistical records is patent. But without figures capable of intelligent interpretation, we are seriously handicapped indeed. William Thomas Kelvin expressed the need adequately and succinctly, "... when you can measure whatever you are talking about, and express it in numbers, you know something about it. But when you cannot measure it in numbers your knowledge is of an inadequate and unsatisfactory kind."'

Especially in research libraries, librarians are almost universally disinclined toward maintaining such records and presenting them in a utilitarian style. ${ }^{3}$ Heinrich Simon observed almost half a century ago that a librarian shudders before a statistical report form as does a hard-pressed doctoral candidate before his committee. Also, Georg Leyh, of Tübingen, the outstanding authority on statistical records of libraries,

\footnotetext{
1 I am indebted to Charles H. Brown, Ralph M. Dunbar, Clyde Cantrell, and Eugene H.' Wilson for many helpful suggestions of practical value in preparing this article. However, any errors of fact or fallacies of speculation are attributable solely to the author. 2 Popular Lectures and Addresses. London, Macmillan, 1889-94, I, 80; cited apud Adams, Randolph G. Three Americanists. Philadelphia, University of Penn-

sylvania Press, r 939 , p. 53.

${ }^{3}$ Brown, Charles H. "Statistical Data and Their Use in the College Library." A.L.A. Bulletin 30:225 28, April 1936; Simon, Heinrich. ("Osmin"). "Bib. liotheksstatistische Kuriosa." Zentralblatt für Bibliothekswesen 21:512-15, 1904. Leyh, Georg. "Die Grundlagen einer internationalen Bibliotheksstatistik," p. ro3. (In First International Congress of Libraries p. ro3. (In First International Congress of Libraries Libreria dellow Stato, 1931-33, IV, 103-19); and Leyh, Georg. "Die Bibliotheksstatistik." Zentralblatt für
} Bibliothekswesen 40:439, 1923 .

has justly looked with suspicion on librarians who consider themselves above the allegedly irksome tasks of compiling and reporting statistics. ${ }^{4}$

The history of the development of statistical records in libraries might well be the subject of a monograph. There is a fairly good introduction to it by Georg Leyh in the second volume of the Handbuch der Bibliothekswissenschaft. However, it must be sufficient here to point out that the matter of uniform statistical reporting has been of great concern to American librarians ever since the 1870 's but that no important advances were made before the 1930's. Especially significant is the recent work of a joint committee composed of representatives from the A.L.A., state library agencies, and the U. S. Office of Education, which drew up uniform statistical report forms for both public and academic libraries, the latter entitled Library Statistical Report for Institutions of Higher Education. ${ }^{5}$ This form is used for collecting statistical data both by the A.L.A. and by the Library Service Division of the Office of Education. It is a basic document and represents much intelligent thinking on library problems. However, it has certain limitations, possibly

\footnotetext{
"Leyh, Georg. "Die Grundlagen einer internationalen Bibliotheksstatistik," p. ro3. On the other hand, Randolph G. Adams is thoroughly justified in his twentieth annual report of the William L. Clements Library (Michigan University. The President's Report, 1942-43, p. 257) in stating that "we have always contended that quantitative measurements tell little about this library, so that we have presented this summary before giving the meaningless figure that we added 1453 volumes to the division of printed books during the course of the year." Even Leyh accepts this viewpoint in his article "Statistik," p. 567, in Milkau, Fritz, and Leyh, Georg, eds. Handbuch" der Bibliothekswissenschaft. Leipzig, Harrassowitz, $193 \mathrm{r}$ 40 , II, $566-80$.

U.S. Office of Education. Form 8-072.
} 
because it is still essentially experimental, although there had been some experience with an older A.L.A. form.

\section{Report Form}

While it is not proposed to limit this paper exclusively to a criticism of the $L i$ brary Statistical Report for Higher Institutions, that document will be subject to careful scrutiny inasmuch as it should be the starting point for any attempt to improve uniform university library statistical records. Many suggestions contained in this paper will be practical to only a few librarians for use in their individual statistical reports. If every possible statistical category were included in one questionnaire, it would break down of its own weight and many libraries might refuse to answer it because it would be too cumber-

- some. Some items are especially applicable to university libraries, others to college libraries, and still others to noninstitutional research libraries, which is all the more reason for having separate statistical report forms for each of these three types of libraries. If we feel it desirable to collect highly specialized information which only a few libraries will be able to supply, we might provide supplemental slip sheets with the report forms, instructing libraries to ignore items not pertinent.

An especially suggestive practice is one followed by the New York State Library at Albany. This library publishes in its Annual Report ${ }^{6}$ not only a table of statistical records arranged according to the "Revised Form for College and Reference Library Statistics" issued by the A.L.A. Committee on Library Administration but also other statistical records of specific interest to itself, e.g., the number of volumes acquired by salvage from its fire.

- Subtitle, A Treasure House of. New York History, 1942, 134-35, "Appendix." The reports of this library in recent years are models of both statistical and narrative excellence.

JUNE, 1945

\section{Limitations of Compilations}

In any consideration of statistical records, and especially of compilations based on returns from a number of libraries, we must never forget that lack of space and funds often limits any program to publish them. By reason of this, the A.L.A. and the Office of Education have in their files a great deal of information supplemental to that which has been published.

A fundamental point in connection with statistical records is the comparison of libraries on matters suggested by the various statistical categories. It is natural to compare libraries, even libraries which are not fairly comparable. The popular mind, whether American, French, English, or German, enjoys nothing more than to indulge in the conceit that his particular national library contains more books than any other library in the world. And some librarians will compare everything, even such figures as the soap and towel expenditures in the New York Public Library and the price paid by the Library of Congress for the Vollbehr collection. Since they feel compelled to do this, we should attempt to make statistical records of libraries as comparable as possible. After all, comparisons of an appropriate nature can be useful, particularly when we are interested in trends and problems of development over a period of years. That it is not impossible to collect uniform data on even the most irrational and variable of human activities is illustrated by the magnificent work of the Federal Bureau of Investigation in organizing a system for the collection of uniform crime statistics and publishing them regularly in an intelligible manner.

\section{A Complete List Needed}

The answer to the criticism that the list of institutions on which data have been annually published (by College and $R e$ search Libraries) "needs revision in order 
to include a more representative sampling of libraries, better distributed geographically," ${ }^{7}$ is that the criticism is stated inadequately, without the possibility of a constructive answer from the long viewpoint. Actually, a complete list is needed. Of all types of American libraries on which the A.L.A. has published statistics, only the class including large reference libraries (public libraries serving over two hundred thousand population) is even reasonably complete. We can accept no omissions if we are to put such records to actual use. ${ }^{8}$ The Office of Education's College and University Library Statistics, 1939-40 $0^{9}$ and previous publications in the series of $S t a-$ tistics of Public, Society and School Libraries (irregular from 1870 on), are far more valuable than the compilations for college and university libraries for the same year published in the A.L.A. Bulletin, simply because the former, although including considerably fewer statistical categories, attempts to publish figures on all such libraries. An even more urgent reason for making complete such tables as have been published in College and Research Libraries is that these tables have been the only regularly published figures on many libraries.

7A.L.A. Committee on Statistics. "Annual Report." A.L.A. Bulletin 34:598, Sept. 15, 1940 . See also Burgess, Robert Stone. "The Sources of Library Statistics," Unpublished M.A. thesis, Graduate Library School, University of Chicago, 1942, p. 59 . Burgess aptly points out that the present policy of inclusion of college and university libraries in the published tables of statistical records gathered by the A.L.A. is based more on the willingness of librarians to take time off to return the statistical questionnaire than on an evaluation of these institutions as being in any way typical or representative. Furthermore, in any discussion of statistical work we should be careful to distinguish between functions of collecting and preserving and of publishing.

$8 \mathrm{Mr}$. Dunbar writes: "My experience over the last fifteen years has been that among the reasons for this situation (i.c., incompleteness) has been: ( 1 ) some private institutions feel that their data are their own business; (2') some institutions keep their statistical records in a manner which they feel fits their own particular needs and consequently do not have their figures in a form to comply with the general blank; (3) some do not wish to invite comparisons with other institutions, as they are either too far in advance or institutions, as they are either too far in advance or are too poor; (4) many of the religious institutions
have the complication of 'contributed services' and methods at variance with those at secular institutions." 9 U.S. Office of Education. Biennial Survey of Edu. cation in the United States, I938-40, vol. 2, chap. 6. Washington, Government Printing Office, r943.

\section{An Annual Handbook}

Obviously College and Research Libraries cannot publish complete statistical records of college and university libraries under present arrangements. Perhaps the only way to do this is to publish an annual handbook of statistical records of libraries, including all libraries in the United States, separated into their appropriate classes. This handbook might possibly be combined with the American Library Directory in a publication similar to the Jahrbuch der Deutschen Bibliotheken or Paul Schwenke's Adressbuch. ${ }^{10}$ Probably separate sections should be maintained for (I) university libraries, (2) college libraries, (3) large public reference libraries, and (4) smaller public libraries and large circulating systems of a strictly popular character (e.g., most of the branches of the Circulation Department of the New York Public Library). Due to their very nature, special libraries might perhaps be considered in a separate directory similar to those already issued. ${ }^{11}$

In addition to statistical information, the first number of this handbook might include historical and descriptive information similar to that contained in Schwenke's still invaluable but unrevised Adressbuch. This information might be supplemented irregularly, possibly every five years, but the statistical records of current interest must be published annually. The period covered should be identical for all libraries, insofar as possible. However, it might be necessary to recognize periods of both the calendar year and the fiscal year, inasmuch as the

10 The Jahrbuch has been published fairly regularly since its first volume in 1902 and has undergone fewperhaps too few-changes in scope and content. Paul Schwenke's Adressbuch der Deutschen Bibliotheken. Leipzig, Harrassowitz, 1893; Zentralblatt für Bibliothekswesen, Beiheft no. ro, includes only figures on holdings, book fund, number of employees, and periods when the libraries listed were open and closed. There is also historical, descriptive, and bibliographical information on each library included in the Adressbuch.

11 Burgess, op. cit., p. 76-77, examines and describes present sources for statistical records of special libraries. 
governing bodies of some institutions require reports for one period and others for another. But under no circumstances should reports be included for threequarters of a year.

\section{Inadequate Publication}

Related to the fault of inadequate coverage of institutions is that of inadequate publication of information which is available, a condition which may generally be traced to inadequate funds and shortage of personnel. It is regrettable that the latest compilations in College and Research Libraries failed to include the figures on numbers and salaries of professional assistants. $^{12}$ The A.L.A. probably has spent Headquarters staff man hours on less important matters, and the A.L.A. Bulletin and College and Research Libraries have published many items of less value than this one page. Such important items as the number of days open per year; the schedule of hours in which the library is open (a) for circulation and (b) for reading and study; and the number of newspapers and periodicals currently received, all of which are provided for on the Library Statistical Report Form for Institutions of Higher Education, find no place in the printed tables. There would be no need for omitting them from printed tables if we had an adequately financed yearbook of statistical records.

Special emphasis should be placed by the editors of this proposed yearbook on discouraging "confidential items," particularly those on personnel-salaries, classification,

\footnotetext{
12 It is important to include these categories when we realize that statistical records of personnel are the only categories in which American statistical records are superior to the Swiss (annually published in Der Schweiser Sammler) and the German. On the other hand, even these figures can be improved. Burgess, op. cit., points out on p. $59-60$ that the practice of listing salary ranges by departments rather than giving individual salaries of professional staff members vir. tually nullifies the value of this information except in the few rare cases where there are but two or three professional employees in each department.
}

hours, vacations, and holidays. Eugene $\mathrm{H}$. Wilson directs attention to the fact that in the last published reports the salary of the librarian of the University of Illinois is not reported and the salary of the associate librarian is marked "confidential." However, the biennial report of the trustees publishes the complete salary statistics and accounts for every dollar spent by the university.

From the very beginning of the serious study of statistical records of libraries, the matter of quantitative measurement of book stock has been a point of general disagreement. The University of Göttingen Library was distinctly embarrassed on one occasion because of definitions inadequate for an accurate count of its holdings. In I 854 its size was estimated at 500,000 volumes, but in 1890 , when an exact count was made on the basis of carefully defined terms, it could show only 442,37 I volumes, a shrinkage on paper of 12 per cent in a period of constant expansion.

\section{Definition of Terms}

The problem is basically that of definition of terms. No two libraries seem to agree as to precisely what a volume is and what a pamphlet is, ${ }^{13}$ whether books should be counted by titles or by bound units, whether duplicates are included or not, and

13 The Library Statistical Report for Institutions of Higher Education states that "a volume is any printed, typewritten, mimeographed, or processed work, bound or unbound, which has been cataloged and fully prepared for use." Some libraries distinguish pamphlets pared for use. train (less than one hundred pages in Germany, Switzerland, and the Newberry Library, less than forty-eight in the Bibliothèque Nationale constitute a pamphlet). Others add a certain number of pamphlets to volume [fifteen equal one volume for Schwenke, ten equal one volume for modern German librarians and James Duff Brown in Manual of Library Economy (London, Grafton and Company, 1937; fifth economy (London, Grafton and Company, ${ }^{1937}$ Thomas Franklin Currier in "Harvard Rules for Counting Volumes and Pamphlets" (Library Journal 42:242, 1918) quotes from a pertinent letter from Herbert Putnam: "The disadvantages of the arbitrary distinction between volumes and pamphlets based merely on the number of pages are of course apparent to us, so much so that . . we discard the distinction entirely in our annual reports." 
so on. The innumerable points on which there is disagreement reveal clearly the fact that no two libraries may be fairly compared according to present standards of quantitative measurement. The only immediate aid in this matter would be our handbook of statistical records in which each library's rules for counting its holdings could be stated concisely, perhaps once every five years.

The problem of counting total holdings cannot be solved here. A special committee in the Library of Congress has been trying to work out a basic procedure for an accurate recount of that library for two years without coming to any definite conclusions. While we may never be able to compare libraries accurately on the basis of volume count, it is conceivable that other standards of quantitative measurement of actual holdings may be used as bases. One standard of this sort is measurement of book stock in linear meters or feet.

The notion of measurement in linear meters was first proposed by Christian Berghoeffer, then librarian of the former Rothschild Library in Frankfurt am Main, in his article on "Messen und Zählen bei Festellung des Bücherbestandes" in $1893 .{ }^{14}$ The editors of the Zentralblatt für Bibliothekswesen expressed themselves in a footnote to Berghoeffer's article as being very skeptical of the validity of this procedure. Nevertheless, the idea has gradually won headway in England, Norway, Italy, and Germany. ${ }^{15}$

14 Zentralblatt fïr Bibliothekswesen 10:326-31, 1893 . 15 Madan, Falconer. "Statistical Survey of the Bodleian Library, with Notes on Book Standards, by Bodley's Librarian." Bodleian Quarterly Record I:254-62, ror6. Current numbers of the Annual Re. port of the Library Syndicate, Cambridge University Library, give linear footage of volumes and pamphlets
added to the "Upper Library." Italy. Ministero added to the "Upper Library." Italy. Ministero Italiane nel MDCCCXCVIII; Notizie Storiche, Biblio. graphiche e Statistiche. Rome, Societá Editrice Dante Alighieri, 1900. This Italian compilation not only gives linear meters of shelf space actually occupied by gives linear meters of shelf space actually occupied by
books but also notes the number of linear meters of books but also notes the number of linear meters of
shelf space available for future expansion. "Regler for Bibliotekstatistik." Bog og Bibliotek 6:210-13, 1939.

\section{Linear Measurements}

Berghoeffer's original plea for measurement in linear meters was partially based on the rapidity of his method. The International Federation of Library Associations Sub-Commission on Statistics of Libraries reported that six hundred thousand volumes were measured in four days by one professional and one clerical employee at the University of Tübingen but warned that it will be considerably more difficult for a classified library in which the shelves are not filled solidly. ${ }^{16}$ However, the really significant aspect of the scheme of measuring a collection of books in linear feet is in providing a check against such discrepancies in counting either volumes or titles as may be caused by peculiar administrative procedures of individual libraries. As to methods of measurement in linear feet (or meters), Georg Leyh, a confirmed advocate of measurement, gives very simple instructions: "Length is measured without regard to size or form. Books charged out at taking of the inventory are included in proportion of 33 vols. = I meter's length." ${ }^{{ }_{17}} \mathrm{New}$ accessions could be readily measured simply by filling solidly a new bookshelf of standard size before sending the books to the stack and counting the number of times that the shelf was filled.

As already indicated, measurement has its critics. J. Muszkowski, director of the Biblioteka i Muzeum Ordynacji Krasinskich in Warsaw, argued that measurement was unfair because English publishers bind

${ }^{16}$ [Report]. Publications of the International Federation of Library Associations, IV, 1932-Actes du Comité International des Bibliothèques, $5^{\text {me }}$ Session, Berne, Juin 9.10, 1932, p. 21. However, there has been at least one recent example of a large American library which has been forced to surrender the "Dogma der systematischen Aufstellung" in favor of shelving der systematischen Aufstellung" in favor of shelving frequent shiftings. Such a retreat from classified shelving, if it becomes general, would help open the way for estimating extent of holdings by measurement in linear feet.

${ }^{17}$ "Statistique Internationale des Bibliothèques." Publications of the International Federation of Library Associations, V, 1934-Actes du Comité International des Bibliothèques, 6 me Session, Chicago, October 14, Avignon, November 13-14, 1933, p. 139 . 
more books and use thicker paper than continental publishers. ${ }^{18}$ Paul Gering offers more objections, which are not listed here because he seems to understand measuring as an auxiliary, not as an absolute device for ascertaining the size of a library. ${ }^{19}$ On the other hand, the idea was carried to an absurd extreme when Leyh proposed to measure not only current acquisitions and total holdings but also manuscripts and incunabula. $^{20}$ Measurement is primarily for those parts of the collection which are not otherwise adequately described.

Incunabula, manuscripts, maps, prints, dissertations, photographs, and music should all be counted separately. The $A n$ nual Report of the Library Syndicate, Cambridge University Library, notes whether maps are received by copyright (ordnance, other official, miscellaneous, and atlases), purchase, or presents and exchanges (English and foreign). It might also be advisable to have a separate rubric for Short Title Catalogue books, particularly in reporting annual accessions, as a guide for future revisions of the list of American locations for books printed in England prior to 1640 . If at all possible, it would be desirable at least to give an approximate indication of the proportion of the total number of volumes which are government documents. This practice, which is followed by the American Council on Education's American Universities and Colleges, is especially useful as a qualitative standard for evaluating small college li-

\footnotetext{
18 International Committee of Libraries, Sub-Commission on Library Statistics. [Report]. Publications of the International Federation of Library Associations, V, r934-Actes du Comité International des Biblio thèques, 6me Session, Chicago, October 14, Avignon, November 13-14, 1933, p. 56-57. We need more discus sion of how size, format, kinds of binding, paper thickness, etc., are going to be accounted for in a.system of linear measurement.

19 "Die Bibliotheksstatistik in Deutschland." Allge meines Statistisches Archiv 17:99-100, 1927. This article deserves careful study as the basic work on German library statistics. It will be found that many of the German practices will shed light on problems of American libraries.

${ }_{20}$ "Statistique International des Bibliothèques," loc. cit., p. $144,146$.
}

braries. As for keeping actual statistics of document acquisition, the practice of recording all separate pieces of U.S., foreign, state, and municipal documents may be recommended (e.g., as at Stanford University Libraries). A fair estimate of the number of duplicates available for exchange might be of some value, especially if classified as to subject field.

The Library Statistical Report for Institutions of Higher Education misses the mark completely when "photographs, pictures, prints" are lumped together as though they represented a single type of material. This grouping might conceivably be legitimate in a small public library, where the form is less important than the fact that the items are similar kinds of visual aids, but for a reference library to place its fifteenth-century woodcuts in the same category with the postal cards donated by a library-minded citizen is hardly appropriate.

But perhaps the most important single improvement of methods of counting total holdings would be to draw up uniform methods for counting current acquisitions. The day will come when present holdings are but a fraction of total holdings; and if accessions are counted in a uniform manner over a period of years, there may be some future possibility of both quantitative and qualitative comparison of libraries. At present the Library Statistical Report for Institutions of Higher Learning provides for current acquisitions solely from a fiscal viewpoint, analyzing them only by their source (purchase, gift, exchange, binding of material not included in the first three items, and restoration of volumes previously lost or withdrawn). ${ }^{21}$

21 It would be most desirable for university libraries to analyze their exchanges in some detail in their annual reports, noting especially the numbers of domestic and foreign institutions with which an exchange relationship is maintained for each publication or for all publications of each scientific society or institute which deposits its publications with the library for exchange purposes. The Annual Report of the Li. brary Syndicate, Cambridge University Library, ana- 
A needed improvement in statistical methods of American libraries is to classify current accessions. Everyone concerned with the library would find that a record of this sort would be invaluable. For the scholar it would be a partial guide to the library's holdings in his field. For the lay governing body it would be the most effective way of understanding concretely the library's growth and contents. Above all, for the librarian it would be a guide to book selection, apportionment of funds, evaluation of trends, accurate comparison with other libraries, general policy, and innumerable other possibilities in setting up standards of service. The fact that the Iowa State College Library has a budget of about $\$ 80,000$ for books, periodicals, and binding, as compared with book budgets of $\$ 150,000$ for some other institutions of university rank, does not mean much unless it can be shown that Iowa State's acquisitions are largely confined to the pure and applied sciences. When holdings of the one hundred most frequently cited chemical periodicals were checked in the Union List of Serials, Iowa State ranked among the first four in completeness of its sets, far ahead of many institutions with book budgets two and three times as large. Classification of acquisitions by subject fields would show roughly the same thing over a period of years, although not quite so accurately as this detailed and painstaking study.

Few American libraries entertain such advanced conceptions of statistical records as the Library of Congress, which tells us every year the exact number of volumes classified and shelflisted by the Subject Cataloguing Division in each major classification. The slight additional work of keeping classified records of titles passing through the hands of classifiers and subject catalogers is surely commensurate with the

lyzes presents and exchanges by country of origin. See also Iowa State College Library, Report, 1933-35. 1935 , p. 8. value of the information made available thereby.

An alternative method is to count directly from the shelflist. Most libraries usually let new shelf-list cards, or those to which additions are made, accumulate for a period of one to four or more weeks. When these cards are in their preliminary classified arrangement preparatory to filing, it would be very simple to divide them into classes and count the number of new accession numbers in each class. Libraries which use the original order card as the shelf-list card could also ascertain from this source just how much money is spent for acquisitions in each class. And it cannot be emphasized too strongly that classified acquisitions by volumes or titles mean little unless there is also information as to how much money is spent on each class. Apportionment of book funds by departments of instruction should always be noted separately in the library's annual report, although there may be no way to put this information into statistical tables covering a number of libraries.

For almost half a century the Jahrbuch der Deutschen Bibliotheken has been classifying accession statistics. Acquisitions of books are divided into eleven broad, but well defined, categories, viz., general works; theology; law and political science; economics; medicine; natural sciences and mathematics; technology; horticulture, agriculture, and forestry; history ; philosophy and pedagogy; and art. While undoubtedly there are occasional varying classifications of books by different libraries, the subject classes are broad enough to permit over-all uniformity. We might use the ten main classes of the Dewey decimal system in this country. All librarians are familiar with them, and it is a very simple matter to assign a book to one of the main Dewey classes at the time it is being classified under the Library of Congress system 
or any of those used by such institutions as Princeton or Harvard.

Another important breakdown of new acquisitions almost completely ignored in America is the division of current acquisitions into new and secondhand books. The statistical records of Swiss libraries, published annually since 1929 by the Vereinigung Schweizerischer Bibliothekare in $\mathrm{Der}$ Schweizer Sammler, include tables of percentages for the relative amounts spent on new books, secondhand books, continuations, and periodicals. The Jahrbuch der Deutschen Bibliotheken lists exact expenditures for new books, continuations, periodicals, secondhand books (in two separate sections, (a) from the fifteenth through the seventeenth centuries and (b) from the eighteenth through the twentieth centuries), and manuscripts. The Annual Report of the Library Syndicate, Cambridge University Library, classifies purchases as to whether they are new (subdividing by country of origin), secondhand (no subdivision), or come by "special grant."

Information showing the relative amounts spent on secondhand books and current trade books would seem to be invaluable for the librarian. It is difficult to understand how any workable purchasing policy can be set up without it. Without such figures a librarian is in no position to organize most advantageously large cooperative buying projects. He cannot tell trustees and legislators precisely who is getting his trade or logically present his requests for appropriations. With them, relations between librarians and dealers might be placed on a sounder footing and divested of some of the mutual suspicion which is almost traditional. Particularly in American libraries, which started growing only in the latter half of the nineteenth century and have never had adequate opportunity to acquire systematically books published prior to 1800 , a record of the relative amounts spent for nova and antiquaria would be a significant guide to the extent of the librarian's efforts to satisfy the needs of scholars.

But however useful this information on the relative amounts spent for new and secondhand books may be, it must be recognized that it would necessitate much additional bookkeeping. Before including this item in any statistical report form such as the Library Statistical Report for Institutions of Higher Education, it would be advisable to conduct a special study in order to ascertain how frequently the data need be collected, from what sources they are available, what additional work their compilation might entail, and how far their compilation might be limited to sampling.

Another item which might be considered in recording the disposition of the book fund is the relative amounts spent for domestic and foreign books. The Cambridge University Library classifies its purchases of new books according to whether they are published in the United Kingdom, British possessions, the United States, Germany, France, or elsewhere. A breakdown of this sort was proposed by Leyh in his outline for a system of international library statistics. $^{22}$ These figures might have some significance in revealing the policies of certain municipal public library systems, which have to serve large numbers of patrons whose native language is not English, or for studies similar to Waples and Lasswell's National Libraries and Foreign Scholarship.

Binding is rarely given adequate statistical treatment. The Library Statistical Report for Institutions of Higher Education covers binding only by including a blank for expenditures for "binding and rebinding." Virtually all compilations have a column for bindery expenditures, but none of them

22 "Statistique International des Bibliothèques," loc. cit., p. $144-54$. 
(and few annual reports of individual libraries) gives the actual number of books bound, rebound, repaired, and placed in a quasi-bound state. A rubric to provide for these categories would be significant in that it would show clearly, for example, how a scientific library, in which periodical literature is the most important type of publication received, has far heavier binding loads than a library whose acquisitions are largely books and other types of monographic publications. For all a legislator or trustee knows, a library which reports five thousand dollars in bindery expenditures may be acquiring fifty especially elegant collectors' bindings rather than spreading its resources judiciously for more practical work. Detailed bindery figures are all the more important because there is no direct and constant relation between binding expenditures and expenditures for book purchases. ${ }^{23}$ A significant figure for correlation with bindery statistics might be enumeration of the bound and unbound books received by the library, a practice followed by the Cambridge University Library in recording volumes received by it under the Copyright Act.

A few libraries distinguish themselves for the exactness of their bindery statistics. Especially noteworthy are the analyses of bindery figures given in the Annual Report of the Librarian of Congress, the University of Lund's Arsberättelse, the Jahresbericht of

${ }^{23}$ Leyh, Georg. "Die Grundlagen einer Internationalen Bibliotheksstatistik," loc. cit., p. II4. the Deutsche Bücherei (a model of library statistical records in other respects as well), and the Bodleian's Report of the Curators (otherwise very weak in statistical records). Each of these libraries goes into careful detail as to the number of volumes or pamphlets put into the various types of bindings used by it and the number and nature of repairs. On the other hand, if we compare the headings used for bindery records for each of these libraries, it is clearly impossible to draw up any uniform system of reporting bindery statistics with absolute exactness. However, it would probably be satisfactory to attempt to record: (a) volumes bound or rebound, (b) volumes repaired, and (c) smaller publications placed in various types of pamphlet bindings.

In these days of rapidly increasing costs of materials and labor, it would be of considerable value to maintain vertical records of bindery costs in individual libraries. In the first two decades of this century Princeton kept such figures, and a study of the resultant tables will not be without significance for librarians of today. ${ }^{24}$ For each year we have figures on the number of volumes and pamphlets bound, pamphlets placed in folders, and number of gilding jobs, together with the total cost and cost per volume.

$$
\text { (to be concluded) }
$$

24 "Princeton University Bindery Statistics," Papers and Proceedings of the American Library Institute, 1920 (I921), p. 2 'o.

J. W. Edwards, publisher, Ann Arbor, Mich., will publish during May 1945 a faithful facsimile reproduction, six volumes in ten, of Poggendorf's Biographisch-literarisches Handwörterbuch für Mathematick, Astronomie, Physik und Geophysik, Chemie, Kristallographie und Verwandte Wissensgebiete . . Berlin, Verlag Chemie, I863-1940, at $\$ 228$ the set, under license of U.S. Alien Property Custodian. 